\title{
METHODS OF DOING BUSINESS IN LATIN AMERICA
}

\author{
WOODFIN L. ButTR*
}

Your client, Goodvalue Appliances, Inc., is a successful manufacturer of kitchen utensils and general household appliances with a wide appeal. One day the president of the company calls on you and says that Goodvalue Appliances has decided to expand into the Latin American field. He wants your advice, among other things, as to the best vehicle, corporate or otherwise, for carrying on the business in one or more countries of this hemisphere. The purpose of this paper is to discuss briefly, and from a point of view which will endeavor to be more practical than profound, some of the considerations you will have in mind in formulating your advice.

The desiderata may be summed up, for convenience in analysis, by saying that the vehicle chosen should effectively enable the company to transact its particular business, with the greatest possible simplicity, with a minimum of expense, and with minimum exposure. Goodvalue Appliances will want, first of all, to be able to make valid contracts and enforce them; it will want to keep in its own hands the general conitrol of the policies followed in business transacted in its name or on its behalf. At the same time, it will want to give a proper degree of authority and discretion to its representatives on the ground; and if it is thinking in terms of permanency, it will want to be able to gain and keep the good will and the respect of the government and the people of each country.

From the standpoint of simplicity, businessmen in this country will be thinking about differences of language and commercial usages, the formalities for organization of a local company or domiciliation of a foreign company, and the endless drudgery of consular authentication and legalization of corporate documents of all kinds. Their accountants will be worried about keeping books and records in a foreign language and in compliance with varying local requirements. You will be particularly interested in helping your client avoid unnecessary complications of a legal nature. The matter of expense will be important not only with regard to the initial cost of establishing an organization but from the viewpoint of subsequent cost of maintenance and, perhaps most important, the tax liabilities involved.

Goodvalue Appliances will naturally be willing to subject itself to all proper requirements of each country as to the business carried on in that country. At the

* B.A., 1927, University of Texas; LL.B., r931, Yale University; Dr. en Ciencias Políticas, 1939, Central University of Venezuela. Member of the Bars of Texas, New York, Puerto Rico, and Venezuela. Attorney, Standard Oil Company (New Jersey), New York City. Member, Committee on Latin American Law, Section on International and Comparative Law, American Bar Association. 
same time, it will not want unnecessarily to expose its home organization, or its business or profits in the United States or other countries, to local control or taxation. It may not want to have its assets in this country answerable in enforcement, without review on the merits, of judgments rendered against it in the courts of a country where it is a foreigner.

Thus outlined the questions presented have much in common with those involved in advising a corporate client in this country whether or not to register to do business in states other than that of its incorporation. Their solution depends, in the first instance, on the nature and extent of the business to be transacted and, in the second, on the methods available under the laws of the foreign state or country. ${ }^{1}$ If the proposed business is purely one of marketing on a not too intensive scale, there are many advantages to be gained in working through an independent merchant without the need for any local organization. If the marketing is to be large in volume, or if it is to be accompanied by local production or processing, the company will probably want to select among three methods of establishing its own corporate existence in the country: ( $\mathrm{r}$ ) registration and licensing of the parent company; (2) formation of a new subsidiary company in this country for the purpose of carrying on its business in one or more Latin American countries, and subsequent registration of that company in each country; (3) formation of a local subsidiary company under the laws of the country where the business is to be transacted.

It is surely no longer necessary, by way of preface to a discussion of the provisions of the Commercial Codes of the Latin American republics, to explain to any North American lawyer the broad outlines of the system of Civil and Commercial Codes, and the cleavage between the "civil law" and the "mercantile law" which is traditional in Europe and Hispanic America. ${ }^{2}$ From the very nature of our discussion, we shall deal almost entirely with the various Codes of Commerce, with only occasional reference to the Civil Codes.

For the sake of clarity and coherence, it will probably be helpful to stick fairly close to the system as it is established in one country, with a minimum of digression into variations among the various Codes as to points of detail. 'The law of Venezuela has been selected for this purpose. Its Code of Commerce is a good example of the classic style, with roots in the French and Italian codes of the middle of the last century; it has not been subsequently amended by newer laws to such an extent as to destroy its value as a typical code. Perhaps most important, it is the law with which this writer is most directly and intimately familiar, and is therefore least likely to lead him into pitfalls of ignorance and insufficient understanding.

I The Bureau of Foreign and Domestic Commerce of the United States Department of Commerce has published a series of very useful booklets on the general subject of trading under the laws of various foreign countries, containing not only outlines of the various methods available, but a summary of applicable tax laws, judicial organization and procedure, import and export requirements, etc. See, e.g., Trading under the Laws of argentina (i933); Brazil (1938); Mexico (I935); Peru (I930); Venezuela (I937). See also Obregón, Latin American Commercial Law (ig21).

${ }^{2}$ There is a good exposition in Trading under THE LAws of ARgentina, supra note 1 , at 6-7. See also Schuster, The Judicial Status of Non-Registered Foreign Corporations in Mexico (1933) 7 TuLANe L. REv. 34I; Obregón, op. cit. supra note I, at 9-I5. 


\section{A. The Commission Merchant}

The Venezuelan Code defines a commission merchant as "one who carries on commercial transactions in his own name for the account of a comitente."3 The comitente would be most easily translated into English as the "principal"; but it seems wise to avoid some of the connotations of that word which are not exactly applicable to the relationship between comitente and comisionista. If the commission merchant transacts the business entrusted to him in the name of the comitente, the relationship is declared to be one of pure agency, and the rights and obligations deriving therefrom are subjected to the provisions on mandato, which is regulated in considerable detail in the Civil Code, with the sole exception that, while the agency in civil matters is presumed to be gratuitous, the commercial agency is not." However, so long as the commission merchant transacts the business in his own name there is no privity between the comitente and the third party with whom the commission merchant deals; each has rights and obligations vis-à-vis the commission merchant, but neither has any right of action against the other. ${ }^{5}$

The commission merchant is free to accept or decline any business which is offered him; but if he declines, the law imposes on him the duty not only of getting word to the comitente without delay but of taking in the meantime whatever steps may be necessary to protect the latter's interests from immediate loss or damage, such as deterioration of merchandise, lapsing or forfeiture of a title, or the running of a prescriptive period. ${ }^{6}$ If he does not receive instructions in due course, he may then make a judicial deposit of any goods or other property received by him, and under court order sell enough to reimburse himself for any expenses which he may have incurred. ${ }^{7}$

If he accepts a commission which is offered him, the merchant is under obligation to carry it through to completion. This is a personal duty, and if he delegates its performance to another without the prior authorization of the comitente, he is still responsible for the acts of the substitute; even if he has general authority to delegate performance to others, he must not select a substitute who is notoriously incompetent or insolvent. He must advise his comitente of any delegation of the commission. ${ }^{8}$

The commission merchant must not represent opposing interests in the same transaction without the express consent of the interested parties, but he is ordinarily not under obligation to disclose the name or identity of his comitente to third parties with whom he is dealing. ${ }^{9}$ He must abide strictly by any instructions given by the comitente; but if in his judgment the carrying out of those instructions would result

\footnotetext{
${ }^{3}$ Art. $38 \mathrm{r}$. (Throughout this paper, where no reference is given, citations are to the Venezuela Code of Commerce of June 29, 1919.) For sample code provisions governing the rights and obligations of the commission merchant and his comitente in other countries, along essentially similar lines, see the following (all citations to Codes of Commerce): Argentine, arts. 223-28r; Brazil, arts. 165-190; Chile, arts. 233-324; Colombia, arts. 33I-434; Ecuador, arts. 363-398; Haiti, arts. 90-94; Nicaragua, arts. 398-434; Peru, arts. 237-274; Uruguay, arts. 30I-386.

${ }^{4}$ Art. 384 .

- Art. 385.

${ }^{8}$ Art. 392.

'Art. 383.

${ }^{7}$ Art. 386 .

${ }^{\circ}$ Arts. 393, 382.
} 
in serious damage to the comitente, he may suspend action and ask for further orders. ${ }^{10}$ In extraordinary and unforeseen circumstances, where he has no instructions and not sufficient time to consult the comitente, the commission merchant is to go ahead in the latter's interest; the degree of care imposed on him is that he act in the exercise of his good judgment ("prudencialmente," which to this writer at least does not seem to carry quite the idea of being subject to the test of appraisal by hindsight which "prudently" is likely to have in English), and that he act as he would in the conduct of his own affairs. The same degree of care is required of him in any case in which the comitente has authorized him generally to act as he thinks best. ${ }^{11}$

The commission merchant does not take title to merchandise received by him from the comitente, and goods or merchandise purchased by him for account of the comitente become the property of the latter immediately. On the other hand, the commission merchant does become the owner of money and paper payable to bearer received by him for account of the comitente, and becomes a debtor of the latter accordingly. ${ }^{12}$

The commission merchant must verify the condition of merchandise received by him, and is answerable for his failure to take proper steps for its protection and preservation. ${ }^{13}$ He may not sell on credit unless authorized to do so, and even then may not give credit to a known insolvent or expose his comitente's interests to a manifest risk. Should he fail to observe these restrictions, or should he fail to show in his accounts the names of purchasers on credit, the comitente may demand that the commission merchant pay him in cash. However, the merchant may, so long as he does not have express instructions to the contrary, grant whatever period is usual in the locality for the actual payment of the purchase price in a cash sale. ${ }^{14}$

The commission merchant is entitled to reimbursement of any advances made and expenses incurred in connection with the business entrusted to him, and in addition is entitled to receive a commission or remuneration which, in the absence of agreement, will be fixed by local custom. For the collection of these amounts, the law grants him a privilege and a right of retention applicable to all goods of the comitente in his possession or under his control, including goods in transit. ${ }^{15}$

The commission may be terminated or modified by the comitente at any time. It is automatically terminated by the death of the commission merchant or by his legal disability for any reason to carry out the matters entrusted to him. It is not terminated by the death of the comitente. ${ }^{16}$

\section{B. Registration of a Corporate Vehicle}

As the simplest method of carrying on its affairs directly and in its own name, Goodvalue Appliances can have an agent located in a given country, or travelling

\footnotetext{
${ }^{10}$ Art. 390.

${ }^{13}$ Arts. 388, 389.

${ }^{10}$ Arts. 4II-I 2.
}

${ }^{11}$ Ibid.
${ }^{14}$ Arts. 404-06.

12 Arts. 40r, 389.

${ }^{15}$ Arts. $394,398,399$. 
from country to country; calling on dealers and taking direct orders. ${ }^{17}$ Whether the activities of this agent will constitute "doing business" within any particular country will depend roughly on the same elements which go into the decision of the same question as among the various states of the United States. A merchant is usually defined, for the purpose of determining whether his acts are to be subject to the mercantile law in general or to the civil law, as one who "habitually" carries on commercial transactions; and the same test of habitualness will be of importance in any decision as to whether the acts of a travelling agent constitute "doing business" by the company. As in the United States, the question will in the last analysis be one of fact, to be determined by weighing all the surrounding circumstances. By way of incidental observation, the writer will hazard the opinion that courts in Latin America will be apt to be unimpressed by some of the legalistic distinctions in this regard which are commonly drawn in this country-such for example as the fact that the orders taken by a local office or agent are said to be subject to approval by the home office.

The judicial status of non-registered foreign corporations in the various LatinAmerican republics has been the subject of a considerable body of literature, notably the series of papers sponsored by the Committee on Foreign Law of the Association of the Bar of the City of New York. ${ }^{18}$ These studies reveal a wide variation in the treatment accorded to non-registered foreign corporations under the legislative systems of the countries examined, and the reader is urged to refer to them if the question is of practical importance to him.

The Venezuelan Code fairly adopts a middle of the road attitude. ${ }^{10}$ Foreign corporations which have the principal object of their business in Venezuela are considered by law as domestic companies; foreign corporations which have branches or subsidiary places of business in Venezuela retain their nationality, but are considered as domiciled in the country. Both categories are required to register. Although the writer knows of no cases in point, failure to do so would apparently expose the company to a fine of five hundred bolivares, imposed by Article 26 of the Code on merchants generally who fail to record required documents in the Commercial Registry.

Foreign companies having neither branches nor fixed places of business in Venezuela may transact business ${ }^{20}$ in the country, and may sue and be sued in its courts.

\footnotetext{
${ }^{17}$ The agent who calls on dealers or consumers directly, and takes orders or makes sales in the name of his principal, may be properly distinguished from the travelling representative who merely acts as liaison between his principals and independent commission merchants. In the latter case the travelling representative may find visa requirements varying from one country to another, but he need have little fear that he is exposing his principals to the consequences of "doing business" within any given country.

${ }^{18}$ These papers were published under a common tite, The Judicial Status of Non-Registered Foreign Corporations in Latin-America, in the Tulane Law Review. The law of Chile, Argentina and Uruguay was considered in (1932) 6 TulaNe L. Rev. 558; Brazil (1933) 7 id. 210; Mexico (1933) 7 id. 341; Colombia (r934) 8 id. 542; Ecuador (1935) 9 id. 409; Nicaragua (1935) 1o id. 58; Guatemala (1937) 12 id. 74 .

${ }^{10}$ Arts. $359-62$.

20 "Hacer negocios," which, it has been pointed out, carries more the idea of individual and isolated transactions, and is not so broad as "ejercer el comercio," to "do business" generally. Trading UNDER THE LAWS OF VENEZUELA, supra note 1 , at 63 .
} 
However, it should be noted that, in any suit brought, the opposing party might by proper pleading require the foreign company to prove its legal existence (as a defendant in this country might deny, on information and belief, that plaintiff is a duly organized and existing corporation) and that the documentary proof so required would be substantially the same as that needed for registering the company in the first place.

We can fairly draw a general conclusion by saying that if Goodvalue Appliances has reason to feel, on the basis of the various criteria outlined, that it is actually "doing business" in one or more countries of Latin America, it will not wait long before registering some corporate vehicle through which that business can be regularly and properly carried on.

\section{Registration of a Foreign Company}

The procedure established by the Venezuelan Code of Commerce for the registration of foreign corporations is typical of that in many of the countries of this hemisphere. According to Article 359 of the Code, the necessary documents are the articles of association and other documents required for the formation of the company, according to the laws of its nationality, a certified copy of the pertinent articles of those laws, and a copy of the bylaws of the company. To this list may be added a proper power of attorney for the company's agent, representative, or attorney who is to attend to the registration. ${ }^{21}$ This power of attorney, in addition to authorizing its holder to take the necessary steps for registration of the company, will usually designate him at the same time as its continuing representative in the country, though it is of course perfectly proper to designate some other person. Every registered foreign corporation must have within the country a representative who will be presumed as a matter of law to have full power to bind it in all matters, excepting only the power to alienate the business itself if this power has not been expressly granted.

All these documents must be duly legalized and translated. The process of legalization by the consular or diplomatic representatives in the United States of the country to which the documents are going presents greater or less difficulty depending on the availability of a consular representative and the extent of the authority granted him by his own laws; ${ }^{22}$ the procedure of successive signature legalization by a notary, a county clerk, the Secretary of State of the state, the Secretary of State of the United States, and the diplomatic representative in Washington of the foreign country, is a chore to be avoided if possible. The power of attorney can, if desired, be executed directly in Spanish, either in the usual way before a notary or before the foreign consul, although as a practical matter this last procedure

${ }^{21}$ Art. 359.

${ }^{22}$ The Venezuelan Organic Law of the Consular Service of 1936 authorizes consuls, in general language, to "legalize the signatures of the local authorities when requested to do so by the interested parties." Art. 22, par. 30. In practice, this language is subject to some variation in interpretation, as to what constitutes an "authority," how wide a geographical range is included in "local" authorities, and so on. Consuls will generally legalize signatures of county clerks in the same city where the consulate is located. 
is likely to involve additional complication in the form of tedious insertion of the full text of the document in consular books of record. ${ }^{23}$ Official translations of the other documents involved are ordinarily made by licensed interpreters after the documents, properly legalized, are received in the country where they are to be used.

Under the Venezuelan procedure, all the documents are then presented for record to the Court of Commerce at the place or places where the company plans to establish offices. The bylaws are placed on file where they may be examined at any time; the charter or articles of association, as the case may be, and the extract of the laws of the state of incorporation, are recorded and then published in a local newspaper. ${ }^{24}$ The power of attorney designating the representative of the company is ordinarily recorded both in the regular civil registry office and in the commercial registry carried by the Court of Commerce. ${ }^{25}$ With these steps, the registration of the company is complete and it is ready to do business.

\section{Formation of a Local Company}

In common with many of the Latin American republics, Venezuela does not have a separate corporation law as such. Title VII of Book First of the Code of Commerce deals with "Commercial Companies and Accounts in Participation." The "anonymous company" is one of the three types listed as having juridic personality separate from that of their members, the other two being the "collective name company"the ordinary partnership, in which the partnership obligations are secured by the unlimited joint liability of all the partners, and the "compañia en comandita"-the limited liability partnership, backed by unlimited liability of one or more full partners and by limited liability of one or more limited partners or comanditarios. ${ }^{20}$

As has already been pointed out, the first Latin American Codes of Commerce were largely drawn from the French Code of 1808 , the Italian Code of 1865 , and the Spanish Codes of 1829 and 1885 . The provisions governing the organization and operation of commercial companies show moreover the influence of the French company law of $186 \%$. There has been relatively little innovation in the legislative provisions since that time. As a result, the language of the codes shows plainly that they were drawn primarily to fit the small, home-grown type of company, with a limited sphere of activity and a relatively small number of partners or shareholders. The matters which the codes feel called upon to regulate in detail, and the corporate shenanigans which they are at pains to prevent, are often practices which have long since been discarded in use; and there are many questions of present-day corporate procedure which can only be answered by a liberal application of the principle that whatever is not prohibited is permissible. This last principle will be stoutly defended,

${ }^{23}$ See, e.g., Venezuelan Organic Law on Consular Service, art. 32, par. 4.

24 Art. 359.

${ }^{25}$ Documents for record in the Commercial Registry may be typewritten. Documents to be recorded in the ordinary civil registry office must be manuscript; if a typewritten document is presented, the Registrar first makes and certifies a manuscript copy, and this is the document actually recorded. If the document comes in English, it is common to kill two birds with one stone by having the official translator make his original a manuscript copy.

${ }^{26}$ Art. 207. 
in theory, by any lawyer in Latin America; but it must be confessed that its practical usefulness is considerably impaired by the inflexible rule unconsciously applied by lawyers the world over, that whatever is not familiar is forbidden. However, and in spite of this tendency to extreme conservatism in the interpretation of code provisions in their application to new situations, the writer feels that the typical regime of the Latin American Codes of Commerce affords a fair and workable basis for the organization of local subsidiary companies and permits the accomplishment of almost any legitimate corporate purpose or method..$^{27}$

The Venezuelan code defines the "anonymous company" as one "in which the company's obligations are secured by a known capital and in which the shareholders (socios-literally 'members') are liable only for the amount of their stock."28 It may be formed either by public subscription or by a public or private contract. ${ }^{29}$ The procedure for promotion and organization of a company by public subscription is regulated in detail; but the other method, that of formation by a contract signed by all the incorporators, is almost always the one which best fits the needs of the North American company wishing to organize a local subsidiary. Our discussion will therefore be limited to this procedure, with only incidental mention of steps to be taken in the organization by public subscription.

Article 252 of the Code of Commerce provides that

The company may be formed by means of public or private document, executed by all the subscribers, in which compliance with all legal requirements shall be shown and the directors and persons charged with the duty of acting as comisarios until the first general meeting shall be designated.

There is no requirement as to the number of incorporators or shareholders. The essentially contractual nature of the articles of association would seem to call for at least two incorporators. In practice, three or five incorporators seem to be most frequently used, so as to reduce to a minimum the situation of holding meetings, complete with motions made, seconded and unanimously approved, with only one or two persons present. ${ }^{30}$

If Goodvalue Appliances, Inc., is to have a branch office in Venezuela, its representative in charge of that office will almost surely be one of the incorporators. By giving him or someone else a sufficient power of attorney for the purpose, the parent company can also appear as an incorporator, and subscribe in its own name

${ }^{27}$ For sample code provisions in other countries, see the following Codes of Commerce (some of which, it must be noted, have been amended in varying degree by special legislation, which must be consulted in each case): Argentina, arts. 282-449; Brazil, arts. 295-299, and Decree 2627 of Sept. 26, r940; Chile, arts. 348, 424-469; Colombia, arts. 463, 550-595; Costa Rica, Ley de Sociedades Comerciales, Nov. 24, I909; Ecuador, arts. 26I-356; Haiti, arts. 29-48; Nicaragua, arts. Ir8-132, 20I-286; Peru, arts. 124132, 159-181; Uruguay, art. 387 .

${ }_{28}$ Art. 207. ${ }^{20}$ Arts. 252, 253.

${ }^{30}$ The Venezuelan Civil Code, art. 1708, defines a "sociedad" generally as "a contract by means of which two or more persons agree to put something in common, for the purpose of dividing among themselves the resulting profits." An almost identical definition of mercantile companies is given in the Argentine Code of Commerce, art. 282. Some of the codes specifically require a minimum number of incorporators for a stock corporation (Argentina requires ten; Brazil and the Dominican Republic, seven; Nicaragua, two). 
for the stock to be held by it, although it is usually simpler to have its representative take the stock in his name and later transfer it to the parent company. The latter procedure involves a transfer tax, which the Venezuelan law fixes at one per thousand on the consideration paid for the transfer of share certificates; $;^{31}$ but unless the capital is large, this tax is likely to be no greater than the expense involved in legalizing, translating and recording a power of attorney. Venezuela makes no requirement as to the nationality or domicil of any of the incorporators or shareholders.

The articles of association will be in form not unlike the corresponding document for the formation of a corporation in any of our states. In Venezuela, the code requires ${ }^{32}$ that the articles of association and the bylaws must contain the following:

I. The name and domicil of the company, its establishments and its representatives. The company may not adopt the name of any of its shareholders; its name may either refer to the purpose for which it is formed, or it may be any special designation so long as it differs from the name of any other company already in existence. $^{33}$ Goodvalue Appliances, Inc., may want to call its Venezuelan subsidiary by a name in English, perhaps "Goodvalue Appliances of Venezuela, Compañia Anónima"; or there is nothing to prevent its adopting an all-out Spanish name like "Compañía Anónima Venezolana de Utensilios y Artefactos para el Hogar."

2. The kind of business to which the company is devoted. The object clauses, if drawn by local counsel, will be considerably more concise than is the custom with us. Attorneys in Latin America look with amused wonder on the prolixity of the typical North American legal document; and translators are fairly baffled by clauses of the "take, purchase, buy, acquire, have, hold, own and operate" variety.

3. The amount of the subscribed capital and the amount paid in. The Venezuelan law makes no requirement as to the amount of initial capital with which the company is to be formed. However, Venezuela has no provision for the formation of a company with authorized but unissued shares; the entire capital stock must be subscribed, and each shareholder must have paid in at least $20 \%$ of the value of the shares taken by him. If the stock is to be bearer stock, it must be fully paid. ${ }^{34}$

4. The name and domicil of the subscribers, or the number and par value of shares, stating whether they are registered or bearer shares, whether the registered shares may be converted to bearer and vice versa, and the time and amount of payments to be made by the shareholders.

5. The value of credits and other property contributed in payment for stock. Patent rights, concession rights and property of any kind can be brought into the company in payment for stock subscriptions. The value placed on such rights or property must be approved by the shareholders at the organization meeting; any subscriber participating in the meeting is at liberty to demand that there be an independent expert appraisal before the vote is taken. In the procedure for formation of the company by contract, the approval of the value set will appear from the articles of association. ${ }^{35}$

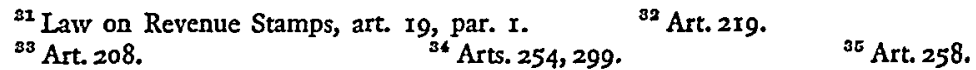


6. The rules in accordance with which balances are to be prepared and dividends declared. The code calls for annual balances and for a summary statement every six months. Dividends are to be paid only out of net realized profits. ${ }^{36}$ Whether stock dividends can be declared is a question about which there is no unanimity of professional opinion, although it has been done in practice. ${ }^{37}$ The same observation holds true as to the declaration of interim dividends out of accumulated surplus in advance of approval of the annual balance sheet.

7. Any particular rights or privileges granted to the promoters.

8. The number of directors, and their rights and obligations, specifying which of them can sign for the company. The board of directors may be composed of any number; the writer has on several occasions participated in the formation of a Venezuelan company with a sole managing director. Directors need not be stockholders; but each must deposit in the company treasury one or more shares of the company's stock to guarantee faithful discharge of his duties, and the usual practice is therefore to have one or more shares stand in each director's name and be deposited by him directly. ${ }^{38}$

Directors are to be elected by the general meeting of shareholders. A common practice is to provide each director with an alternate or suplente, who automatically steps in and acts for him whenever the titular member is incapacitated.

9. The number of comisarios. This useful officer is the shareholders' watchdog, elected by and responsible to them, and his duties are to give them periodic reports as to the conduct of the business by the board of directors. He is something more than an independent auditor employed by the shareholders, as he has unlimited access to all the files and records of the company and is not limited to financial matters; but the role of auditor is as close as our system comes to an equivalent. The semiannual statement of condition and the annual balance sheet and report of the directors are to be submitted to him in advance of the annual general meeting and must be accompanied by his report when they are brought up for approval by the shareholders. He is the normal recipient of complaints by the shareholders against the directors, and if $10 \%$ of them present a complaint which he believes is well founded and urgent, it is his duty to call a special meeting of the shareholders to consider whether any action should be taken..$^{39}$ In the case of a wholly owned subsidiary company, the office of comisario is naturally of much less importance, and is not infrequently filled by one of the company's own accountants.

Io. The powers of the general meeting, and requirements for the validity of its decisions and the exercise of voting rights, if it is desired to set up rules different from those prescribed in specific articles of the Code.

The ordinary general meeting of shareholders is held once a year at least, on the

${ }^{30}$ Art. 312.

${ }^{37}$ In a closely held or wholly owned subsidiary, where there is unanimity of action, it is always possible to follow the procedure of a declared dividend in cash, followed immediately by an increase in capital and a subscription of the increase by the shareholders, to be paid for with the proceeds of the cash dividend. Obviously, however, this procedure may have tax repercussions in this country which would make it unacceptable.

${ }^{38}$ Art. 249.

${ }^{30}$ Arts. 292, 314-16, 310. 
date fixed in the bylaws; and unless these povide a different rule, more than half the stock must be represented for a quorum. A call for the meeting is to be issued by the board and published in a local newspaper at least five days before the date set, although there seems to be no reason to question the validity of a meeting held without a call if all the stock is represented. If a quorum is not present on the date set, another meeting is automatically held three days later, without a new call; if there is still no quorum, a call will be issued for a third meeting to be held five days later, with the statement that the meeting will be held with whatever shareholders are present. Special meetings may be called by the board at any time, and must be called when demanded by one fifth of the shareholders. ${ }^{40}$

Shareholders may attend the meetings in person or be represented by proxy. ${ }^{41}$ Members of the board of directors, comisarios and managers may not act as proxies; ${ }^{42}$ but aside from this statutory limitation, the matter is considered to be a purely internal one within the control of the meeting. There is no particular requirement as to the form or content of proxies, or as to authentication or legalization of signatures thereon. If the shares are bearer shares, it is a recognized practice for the bylaws to provide for proof of ownership by depositing the share certificates in a bank or similar institution as an alternative to physical exhibition of the certificates at the meeting.

The agenda of the ordinary general meeting include discussion and approval or modification of the balance sheet, election of directors, election of one or more comisarios, fixing compensation of directors and comisarios, and any other business specially brought up for action.

There is no provision in the Venezuelan Code as to place of holding meetings of shareholders. In the absence of such a provision, the writer has felt rather strongly that the shareholders themselves are at perfect liberty to designate as the place of meeting any location convenient to them, even though it be away from the corporate domicil and outside the country, and that they may by the same token give the board of directors at least a limited discretion in the matter. It must however be confessed that this view is regarded as heresy by many Latin American attorneys. Unless there is some strong reason to the contrary, therefore, it is advisable to hold all meetings of stockholders at the corporate domicil. The same observation can be made as to the normal and usual place of meeting of the board of directors. ${ }^{43}$

${ }^{50}$ Arts. 276-28r.

41 The Argentine Code contains a provision, art. 350 , to the effect that no shareholder, however large his holdings, may vote more than one tenth of the capital, nor more than two tenths of the votes present at the meeting. This exaggerated protection of minority interests is roundly criticized by various commentators. Malagarriga, Código de Comercio (i927); Rivarola, Sociedades Anónimas (19ז8) par. 56, citing CÉlerier, Etude sur les Sociétís ANonymes (1905) 99. The Nicaraguan Code has an identical provision. Uruguay limits a holder to three votes if there are less than one hundred shares and to six votes if there are a hundred or more. Costa Rica has a sliding scale requiring first one share, then five shares, then ten shares for one vote as a person's holdings increase. All such restrictions will of course have an important bearing on the question of organizing subsidiary corporations under the laws of the particular countries involved.

12 Art. 290.

${ }^{43}$ In connection with the general problem of what corporate functions must be necessarily carried on at the corporate domicil, see Bosvieux, in (1907) Journal des Socítí́s Civiles et Commerciales, 488 489; Wahl, writing in the same periodical (19I1) id. 253; DE Gregorio, Delle Societa e delle Associazioni 
II. The time for commencement of the corporate existence and its duration. A common provision is to the effect that the company shall have a life of indefinite duration.

When the articles of association and the bylaws are completed, they will be signed by all the incorporators. The directors designated therein-usually the incorporators themselves-will then prepare a separate petition addressed to the local Court of Commerce, presenting the articles and the bylaws for record, and attaching evidence of the receipt by the company of the required minimum $20 \%$ payment from each shareholder. This evidence commonly consists of a certificate of deposit from a local bank, showing that the necessary amount of money has been deposited to the order of the new company.

The presentation for record is to be made within fifteen days after the execution of the corporate documents. It is the duty of the court to satisfy itself that all legal requirements in connection with the formation of the company have been met; the court then orders the registration and publication of the articles of association and the filing of the bylaws. ${ }^{44}$ Amendments to the articles or the bylaws may be made by the shareholders at any time, but require registration and publication in the same manner as the original documents. ${ }^{45}$

Share certificates must be signed by two members of the board of directors, and must contain certain specified information about the company, including the date of the annual meeting. Bearer shares pass title by delivery of the share certificate; registered shares are transferable only on the books of the company, and the company's stock records are the only legal proof of ownership. ${ }^{46}$

General obligations of the company may only be issued by authority of a meeting of shareholders, and may not exceed the existing capital of the company. This restriction, however, does not apply to bills of exchange, to deposit accounts, to nonnegotiable obligations to a designated payee, or to obligations arising out of particular transactions. ${ }^{47}$ Advances on open account by a parent company to its subsidiary, for example, would seem clearly to fall outside the restriction.

\section{Relative Merits of the Methods Outhined}

At the beginning of this paper we set down some of the practical considerations which a North American company would have before it in choosing a vehicle for the conduct of its business operations in Latin America. We have drawn the broad outlines of the most readily available methods of doing business in one country, Venezuela, as having a legal system which is fairly representative of that which will be found in most of the others. We ought now to set the desiderata postulated against the means available, and see whether we can give the president of Goodvalue Appliances, Inc., some concrete advice.

The decision as betwreen establishing corporate existence within each country, on

Comerciali in 4 Il Codice di Comercio Commentato (6th ed. Turin 1938) 88; I Soprano, Trattato Thorico Pratico delle Societa Commerciazi (Turin I934) 527-529. The writer's own views were set out in a paper La Compañía Anónima Venezolana ante el Progreso Mundial (Caracas 1939).

4 Art. 220.

${ }^{40}$ Art. 301.

${ }^{45}$ Art. 226.

17 Art. 305. 
the one hand, and doing business through one or more independent commission merchants, on the other, will be taken on business rather than on legal grounds. If the company is going into a country on a small scale, or is feeling its way at the beginning, almost all considerations of economy and simplicity would seem to be on the side of the commission merchant as an entirely adequate vehicle.

It will only be in a rare case with special circumstances that an American business will want to register its principal North American company to do business in foreign countries. As has already been suggested, this course has two chief disadvantages, both arising out of the fact of submitting the parent company to foreign jurisdiction. The first is the possibility that the company's overall capitalization, business turnover or profits might be used as a measure of local taxation; the second is the prospect that judgments against it in local courts, where the company is appearing as a presumably wealthy foreigner, might be enforced against its assets in this country without a review on the merits. An equally practical, though perhaps less vital, objection is the fact that Latin American countries generally require all changes in bylaws, annual balance sheets, etc., to be filed and recorded, and this will entail constant trouble and expense and perhaps disclosure of confidential information having no connection with the country in question.

As between forming a special North American company for registration in Latin America and forming a Latin American subsidiary, the balance is so close that this writer has been inclined to throw the decision into the hands of United States tax counsel. Unless the capital is very large, the cost of forming a local company will likely be not much more than the cost of qualifying one which has been organized abroad and must be registered in the country. Once established, the obligations imposed on either type, as to local taxation, bookkeeping, filing of documents, and general subjection to the laws of the country, are substantially identical. The same may be said of the rights and privileges of either company and its standing in the country's courts. The organization and functioning of a North American company is likely to appear simpler, because more familiar, to North American counsel; on the other hand, there seems reason to believe that there is a measurable increase in local good will to be gained by a local company. The tendency today seems to be all in the direction of formation of local companies under the laws of the countries where the business is to be carried on.

Goodvalue Appliances' success or failure in Latin America will depend, in the last analysis, less on its form of organization than on the men who represent it, from the first visitor to the permanent staff of a branch factory or selling organization. The company's representatives should be the best it can spare from its own organization or find outside; Latin Americans are quick and keen judges of individuals, and are not likely to conceive of a first-class company behind any but a first-class man. Slick-tongued super-diplomats are no more a business necessity in Latin America than they are in this country; but the homespun American qualities of honesty, straightforwardness, simple courtesy, and respect for the other fellow's point of view will evoke a quick and sure response in kind from Brownsville to Tierra del Fuego. 